\title{
Dariusz Głuszczuk
}

Uniwersytet Ekonomiczny we Wrocławiu

e-mail: dariusz.gluszczuk@ue.wroc.pl

\section{PRZESZKODY DLA DZIAŁALNOŚCI \\ INNOWACYJNEJ PRZEDSIĘBIORSTW \\ W WOJEWÓDZTWIE DOLNOŚLĄSKIM \\ W LATACH 2004-2006, 2008-2010 I 2012-2014}

\section{BARRIERS FOR INNOVATION ACTIVITIES \\ CARRIED OUT BY INDUSTRIAL ENTERPRISES IN LOWER SILESIAN REGION IN THE YEARS 2004-2006, 2008-2010 AND 2012-2014}

DOI: 10.15611/pn.2018.517.05

JEL Classification: L26, O31

Streszczenie: W sprawozdaniach o innowacjach w przemyśle (PNT-02) i sektorze usług (PNT-02/u) operuje się uboższą gamą przeszkód działalności innowacyjnej przedsiębiorstw niż w przypadku zaleceń Oslo Manual 2005. Mankament ten pogłębia częściowa zmiana obserwowanych utrudnień i ich nazewnictwa w ramach PNT-02 i PNT-02/u (2015 r. w relacji do poprzednich edycji badań). Ponadto wybrane - w ramach wariantowych rozwiązań OM 2005 - zasady gromadzenia danych nie wydają się odpowiadać potrzebom użytkowników statystyki publicznej (np. okres objęty obserwacją - 3 lata). Wszystko to zawęża pole analiz, ale nie przekreśla możliwości identyfikacji kluczowych barier dla innowacji. Kolejne trzy edycje badań wskazują, że istotne utrudnienia działalności innowacyjnej przedsiębiorstw w województwie dolnośląskim wywołują czynniki kosztowe (brak możliwości finasowania ze źródeł wewnętrznych oraz zewnętrznych) oraz rynkowe (niepewny popyt na innowacyjne produkty, opanowanie rynku przez dominujące przedsiębiorstwa).

Słowa kluczowe: procesy innowacyjne, przeszkody dla innowacji, sprawozdania o innowacjach.

Summary: The reports on innovations in industry (PNT-02) and service sector (PNT-02/u) use a more limited range of obstacles to innovative business activities than in the case of guidelines presented by the Oslo Manual 2005. This shortcoming is deepened by the partial change of the observed difficulties and their terminology within the framework of PNT-02 and PNT-02/u (2015 in relation to previous editions of the research). Moreover, the selected - as part of OM 2005 variant solutions - data collection rules do not seem to correspond with the needs of public statistics users (e.g. observation period -3 years). It narrows down the area of analyses, but does not eliminate the possibility for identifying the key innovation barriers. The subsequent three editions of the research indicate that the significant difficulties for innovation activities in Lower Silesian enterprises result from cost-oriented (the absence of funding from 
internal and external sources) and market factors (unsteady demand for innovative products, market ruled by dominating enterprises).

Keywords: innovative processes, barriers for innovations, reports on innovations.

\section{Wstęp}

Procesy innowacyjne przedsiębiorstw ogranicza wiele barier. W Oslo Manual 2005 systematyzuje się je, wyróżniając przeszkody kosztowe, rynkowe, instytucjonalne, związane z wiedzą oraz innymi powodami nieprowadzenia działalności innowacyjnej. Rozwinięciem tej klasyfikacji są sugestie określające ogólne zasady gromadzenia danych. $\mathrm{W}$ ich ramach proponuje się $\mathrm{m}$.in. wariantowe rozwiązania $\mathrm{w}$ zakresie częstotliwości prowadzenia badań i okresu obserwacji, a także wskazuje się na potrzebę identyfikacji wag (znaczenia) poszczególnych przeszkód. Zalecenia te znajdują pewne odzwierciedlenie w polskich sprawozdaniach o innowacjach w przemyśle (PNT-02) i sektorze usług (PNT-02/u). Za cel niniejszego artykułu przyjęto ocenę stosowanych rozwiązań w sferze gromadzenia danych o przeszkodach dla innowacji (GUS, sprawozdania PNT-02 i PNT-02/u) na tle postulatów Oslo Manual 2005, a także identyfikację kluczowych barier działalności innowacyjnej dolnośląskich przedsiębiorstw w latach 2004-2006, 2008-2010 i 2012-2014.

\section{Przeszkody dla innowacji - ujęcie Oslo Manual i GUS}

Identyfikacja przeszkód dla innowacji łączy się z ich systematyką oraz określeniem ogólnych zasad gromadzenia danych, odnoszących się m.in. do populacji docelowej, częstotliwości prowadzenia badań, okresu objętego obserwacją oraz sposobu ustalania znaczenia poszczególnych barier. W pierwszej kwestii autorzy Oslo Manual 2005 proponują, by czynniki utrudniające procesy innowacyjne grupować w ramach przeszkód kosztowych, rynkowych, instytucjonalnych oraz związanych z wiedzą lub innymi powodami nieprowadzenia działalności innowacyjnej. Klasyfikacja ta została częściowo odwzorowana $\mathrm{w}$ sprawozdaniach o innowacjach $\mathrm{w}$ przemyśle (PNT-02) i sektorze usług (PNT-02/u) za lata 2004-2006 i 2008-2010. W kolejnej edycji badań (2015 r.) zrezygnowano ze wspomnianej systematyki, zestawiając czynniki utrudniające działalność innowacyjną w pytaniach o przyczyny braku innowacji i bariery innowacyjności. Znacznie większe różnice między zaleceniami Oslo Manual a sprawozdaniami PNT-02 oraz PNT-02/u można odnotować po stronie obserwowanych czynników, barier działalności innowacyjnej (tab. 1).

Zakres zbieranych informacji w ramach sprawozdań PNT-02 i PNT-02/u jest pod wieloma względami uboższy niż w przypadku zaleceń Oslo Manual 2005. W formularzach tych:

- rezygnuje się z korelowania przeszkód działalności innowacyjnej z typami innowacji (zob. [OECD/European Communities 2005, s. 113]), 
- wyklucza się z barier procesów innowacyjnych firm czynniki instytucjonalne (brak infrastruktury, słabość praw własności, ustawodawstwo, uregulowania prawne, normy, opodatkowanie),

- niejednokrotnie ogranicza się rodzaje przeszkód, które mogą wystąpić w określonej grupie czynników utrudniających działalność innowacyjną (np. czynniki dotyczące wiedzy nie obejmują skostniałości organizacyjnej wewnątrz przedsiębiorstwa, niedostatecznego potencjału innowacyjnego itd.),

- agreguje się pozycje Oslo Manual (np. brak zewnętrznych środków finansowych bez wyodrębnienia przeszkód związanych z dostępnością do kapitałów wysokiego ryzyka i publicznych źródeł finansowania).

Tabela 1. Przeszkody dla innowacji - zalecenia Oslo Manual a sprawozdania PNT-02 i PNT-02/u

\begin{tabular}{|c|c|c|c|c|}
\hline & Oslo Manual 2005 & $\begin{array}{c}\text { PNT-02, PNT-02/u } \\
\text { za lata } \\
\text { 2004-2006 i 2008-2010 }\end{array}$ & & $\begin{array}{c}\text { PNT-02, PNT-02/u } \\
\text { za lata } \\
\text { 2012-2014 }\end{array}$ \\
\hline 1 & 2 & 3 & 4 & 5 \\
\hline \multirow{7}{*}{ 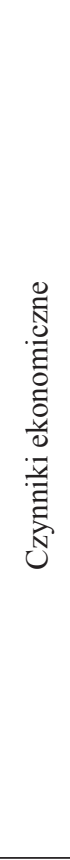 } & $\begin{array}{l}\text { Postrzegane ryzyko jest } \\
\text { zbyt wysokie }\end{array}$ & - & \multirow{9}{*}{ 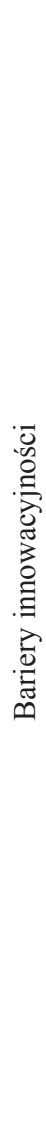 } & - \\
\hline & Zbyt wysokie koszty & $\begin{array}{l}\text { Zbyt wysokie koszty } \\
\text { innowacji }\end{array}$ & & - \\
\hline & $\begin{array}{l}\text { Brak środków finansowych } \\
\text { w przedsiębiorstwie }\end{array}$ & $\begin{array}{l}\text { Brak środków finansowych } \\
\text { w przedsiębiorstwie lub } \\
\text { w grupie przedsiębiorstw }\end{array}$ & & $\begin{array}{l}\text { Brak możliwości } \\
\text { finansowania innowacji } \\
\text { ze źródeł wewnętrznych } \\
\text { przedsiębiorstwa }\end{array}$ \\
\hline & $\begin{array}{l}\text { Brak zewnętrznych } \\
\text { środków finansowych: }\end{array}$ & $\begin{array}{l}\text { Brak środków finansowych } \\
\text { ze źródeł zewnętrznych }\end{array}$ & & $\begin{array}{l}\text { Brak możliwości finansowania } \\
\text { innowacji ze źródeł } \\
\text { zewnętrznych - kredytów } \\
\text { bądź środków w ramach } \\
\text { finansowania private equity } \\
\text { (w tym venture capital) }\end{array}$ \\
\hline & $\begin{array}{l}\text { - kapitał wysokiego ryzyka } \\
\text { (venture capital) }\end{array}$ & - & & - \\
\hline & $\begin{array}{l}\text { - publiczne źródła } \\
\text { finansowania }\end{array}$ & - & & - \\
\hline & - & - & & $\begin{array}{l}\text { Trudności w pozyskaniu } \\
\text { publicznych grantów bądź } \\
\text { subsydiów na innowacje }\end{array}$ \\
\hline \multirow{2}{*}{ 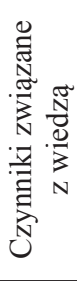 } & $\begin{array}{l}\text { Niedostateczny potencjał } \\
\text { innowacyjny }(B+R, \text { prace } \\
\text { projektowe itp.) }\end{array}$ & - & & - \\
\hline & $\begin{array}{l}\text { Brak wykwalifikowanej } \\
\text { kadry: }\end{array}$ & $\begin{array}{l}\text { Brak wykwalifikowanego } \\
\text { personelu }\end{array}$ & & $\begin{array}{l}\text { Brak personelu } \\
\text { o odpowiednich } \\
\text { umiejętnościach } \\
\text { w przedsiębiorstwie }\end{array}$ \\
\hline
\end{tabular}


Tabela 1, cd.

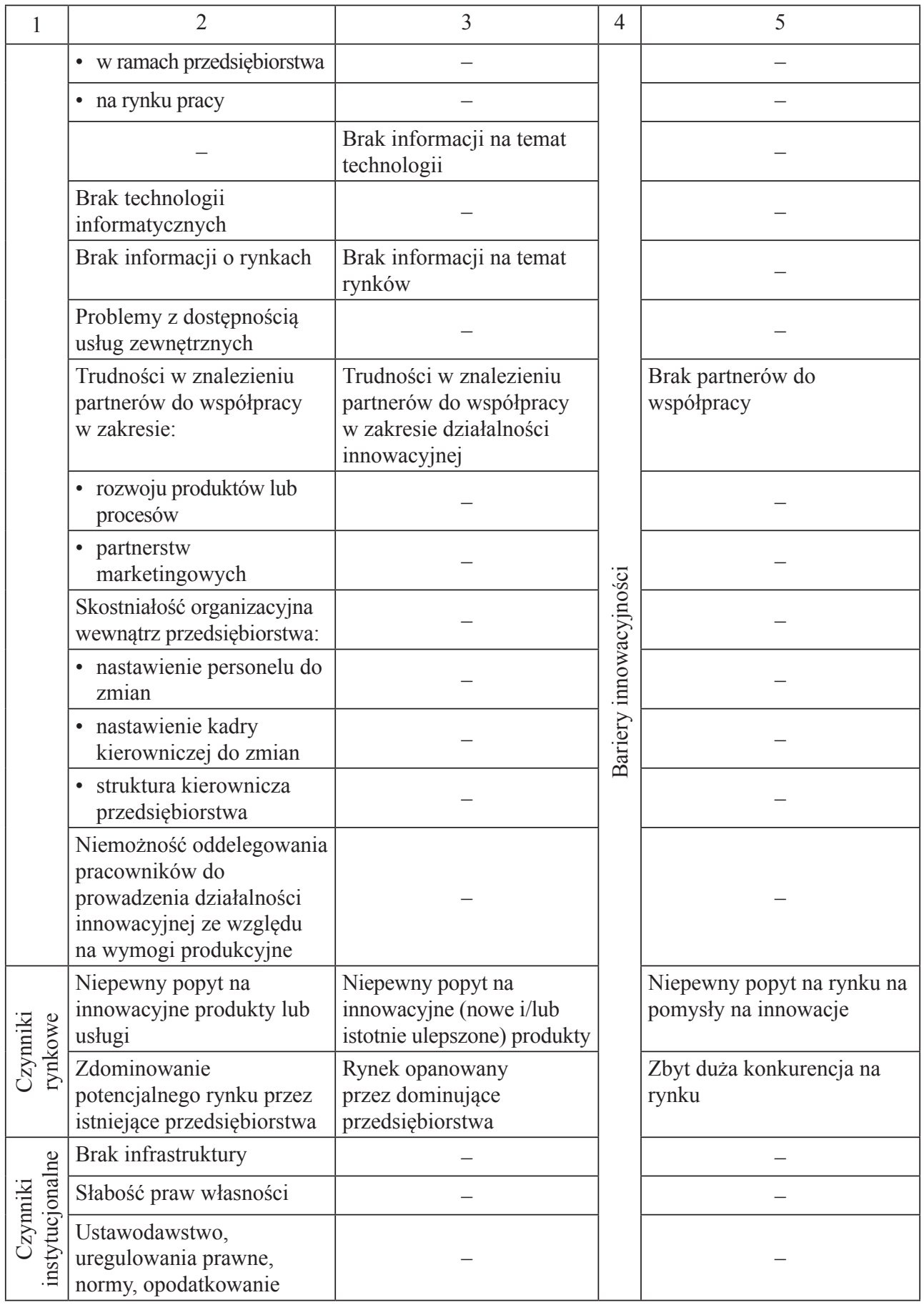




\begin{tabular}{|c|c|c|c|c|}
\hline 1 & 2 & 3 & 4 & 5 \\
\hline \multirow{4}{*}{ 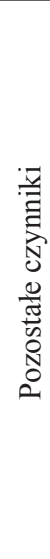 } & $\begin{array}{l}\text { Brak potrzeby prowadzenia } \\
\text { działalności innowacyjnej } \\
\text { ze względu na wcześniejsze } \\
\text { innowacje }\end{array}$ & $\begin{array}{l}\text { Brak potrzeby prowadzenia } \\
\text { działalności innowacyjnej } \\
\text { ze względu na } \\
\text { wprowadzenie innowacji } \\
\text { w latach poprzednich }\end{array}$ & \multirow{4}{*}{ 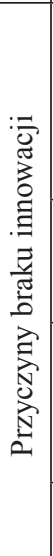 } & $\begin{array}{l}\text { Brak potrzeby wdrażania } \\
\text { innowacji ze względu na } \\
\text { wcześniejsze innowacje }\end{array}$ \\
\hline & $\begin{array}{l}\text { Brak potrzeby ze względu } \\
\text { na brak popytu na } \\
\text { innowacje }\end{array}$ & Brak popytu na innowacje & & $\begin{array}{l}\text { Niski popyt na innowacje na } \\
\text { rynku }\end{array}$ \\
\hline & - & - & & $\begin{array}{l}\text { Brak potrzeby wdrażania } \\
\text { innowacji ze względu na } \\
\text { niewielką konkurencję na } \\
\text { rynku }\end{array}$ \\
\hline & - & - & & $\begin{array}{l}\text { Brak dobrych pomysłów na } \\
\text { innowacje }\end{array}$ \\
\hline
\end{tabular}

Źródło: opracowanie własne na podstawie [OECD/European Communities 2005, s. 113; GUS 2007a, s. 4; GUS 2007b, s. 4; GUS 2011a, s. 7; GUS 2011b, s. 7; GUS 2015a, s. 7-8, GUS 2015b, s. 7-8].

Ponadto, porównując sprawozdania o innowacjach w przemyśle i sektorze usług za lata 2004-2006 i 2008-2010 z ich odpowiednikami za lata 2012-2014, należy zauważyć, że:

- zmieniono nazewnictwo niektórych przeszkód, co może wywoływać wątpliwości interpretacyjne, a w skrajnych przypadkach podważać porównywalność zbieranych danych (np. brak środków finansowych w przedsiębiorstwie lub w grupie przedsiębiorstw zastąpiono brakiem możliwości finansowania innowacji ze źródeł wewnętrznych przedsiębiorstwa, a w miejsce rynku opanowanego przez dominujące przedsiębiorstwa wprowadzono zbyt dużą konkurencję na rynku),

- w ostatniej edycji badań zrezygnowano z obserwacji takich barier, jak: zbyt wysokie koszty innowacji, brak informacji na temat technologii, brak informacji na temat rynków oraz wprowadzono nowe dotychczas nie uwzględniane czynniki utrudniające działalność innowacyjną (trudności w pozyskaniu publicznych grantów bądź subsydiów na innowacje, brak dobrych pomysłów na innowacje) lub podważające jej zasadność (brak potrzeby wdrażania innowacji z uwagi na niewielką konkurencję na rynku).

Sugestie Oslo Manual nie odnoszą się wyłącznie do klasyfikacji i specyfikacji przeszkód dla innowacji przedsiębiorstw. Ich treści określają również zasady gromadzenia danych. Najważniejsze z nich dotyczą populacji docelowej, częstotliwości prowadzenia badań, okresu objętego obserwacją oraz sposobu ustalania znaczenie poszczególnych barier.

Populacja docelowa - według OM - powinna obejmować sektor przedsiębiorstw, w tym podmioty dokonujące i niedokonujące innowacji oraz prowadzące i nieprowadzące działalność badawczo-rozwojową [OECD/European Communities 2005, s. 118]. 
Postulat ten ma istotne znaczenie, gdyż mogą istnieć powody zaniechania procesów ukierunkowanych na implementację nowych lub znacząco udoskonalonych rozwiązań, a także przyczyny je spowalniające. Nie można również wykluczyć sytuacji, w której rzeczywiste rezultaty działalności innowacyjnej będą inne od oczekiwanych. Odmienne konsekwencje barier dla innowacji wyraźnie wskazują, że czynniki utrudniające te procesy mają różną siłę oddziaływania. Ich wagę (znaczenie) trzeba ustalać w trakcie badań statystycznych, by właściwie rozpoznać nie tylko zbiór, ale i skalę problemów proinnowacyjnych przedsiębiorstw. Kwestią otwartą w tej sugestii jest sposób ustalania rangi poszczególnych przeszkód [OECD/European Communities 2005, s. 112]. Dokładniej, choć nie w pełni precyzyjnie, formułuje się propozycję dotyczącą częstotliwości prowadzenia badań. $\mathrm{W}$ tym przypadku postuluje się, by były one powtarzane co dwa lata, a gdy nie pozwalają na to względy ekonomiczne - raz na trzy lub cztery lata, choć zaznacza się, że najlepiej byłoby organizować je co roku [OECD/European Communities 2005, s. 1129]. Podobną wariantowość rozwiązań zawiera propozycja dotycząca okresu, który należy objąć obserwacją. Zdaniem autorów OM nie powinien on być krótszy niż rok i nie dłuższy niż 3 lata [OECD/European Communities 2005, s. 61]. Z innych rekomendacji OM warto przytoczyć następujące:

- badaniem należy objąć wszystkie jednostki statystyczne posiadające co najmniej 10 pracowników, przy czym użyteczne może się okazać uwzględnianie jednostek zatrudniających mniej niż 10 osób [OECD/European Communities 2005, s. 118-119],

- zbiorowością badaną może być cała populacja lub próba statystyczna [OECD/ European Communities 2005, s. 120],

- podzbiory populacji docelowej mogą tworzyć m.in. podmioty wyróżnione według klas wielkości, rodzaju działalności podstawowej oraz lokalizacji (regiony) [OECD/European Communities 2005, s. 120].

W badaniach prowadzonych przez GUS populację docelową tworzą wszystkie przedsiębiorstwa przemysłowe i usługowe, a dobierana $\mathrm{z}$ nich próba statystyczna zawiera jednostki zatrudniające powyżej 9 osób, z wyjątkiem firm przemysłowych o liczbie pracujących 50 i więcej, które w pełni objęto obowiązkiem sprawozdawczym [GUS - Urząd Statystyczny w Szczecinie 2015, s. 18-19]. Przyjęte cechy warstwujące zapewniają m.in. reprezentatywność próby na poziomie regionów. Szkoda, że dane dotyczące barier działalności innowacyjnej są zbierane tylko raz na 4 lata i odnoszą się do trzyletnich okresów obserwacji. W sprawozdaniach o innowacjach w przemyśle (PNT-02) i sektorze usług (PNT-02/u) pytania dotyczące przeszkód dla innowacji pojawily się w formularzach z 2007, 2011 oraz 2015 roku i odnosiły się odpowiednio do lat 2004-2006, 2008-2010 oraz 2012-20141. Powtarzalność tych

\footnotetext{
${ }^{1}$ Obowiązujące w roku 2017 formularze PNT-02 i PNT-02/u nie wydają się wprowadzać trwałych zmian w zakresie częstotliwości prowadzonych badań nt. barier działalności innowacyjnej, choć uwzględniono w nich przywołaną problematykę [GUS 2017a, s. 9-10; GUS 2017b, s. 9-10]. Decyzja ta zapadła zbyt pochopnie, bo zachowując trzyletni okres obserwacji, należałoby uwzględnić iden-
} 
badań, podobnie jak i okres objęty ich obserwacją, można byłoby lepiej dostosować do potrzeb użytkowników statystyki publicznej. Równie krytycznie można odnieść się do przyjętego sposobu określania rangi poszczególnych przeszkód. Ocena stopnia utrudnienia procesów innowacyjnych opiera się na cechach porządkowych, kwantyfikujących natężenie badanych właściwości przedstawionych w sposób opisowy (stopień znaczenia: 1 - wysoki, 2 - średni, 3 - niski, 4 - bez znaczenia). Rozwiązanie to pozwala uchwycić rangę problemu, ale nie wskazuje na jego konsekwencje (np. zaniechanie działalności innowacyjnej).

Reasumując, należy stwierdzić, że przyjęte rozwiązania statystyczne umożliwiają identyfikację barier procesów innowacyjnych przedsiębiorstw na poziomie regionów wraz z uchwyceniem siły ich odziaływania, ale w analizie tej porównania w czasie ograniczają się wyłącznie do przeszkód uwzględnionych w trzech edycjach badań. Ponadto zastosowana gradacja istotności poszczególnych ograniczeń wskazuje, że poważne utrudnienia działalności innowacyjnej wywołują tylko te czynniki, którym przypisano duże znaczenie.

\section{Bariery dla innowacji w populacji dolnośląskich przedsiębiorstw}

Przedsiębiorstwa Dolnego Śląska z różną częstotliwością wskazują na duże znaczenie poszczególnych barier działalności innowacyjnej (tab. 2).

W sektorze przemysłowym najistotniejsze przeszkody procesów innowacyjnych tworzą czynniki kosztowe. Na brak środków finansowych w przedsiębiorstwie lub grupie przedsiębiorstw (lata 2012-2014 - brak możliwości finasowania innowacji ze źródeł wewnętrznych przedsiębiorstwa) wskazało od 29,3\% (lata 2012-2014) do $36,7 \%$ (lata 2004-2006) jednostek objętych badaniem. Niższy, ale wysoce dotkliwy był brak środków finansowych ze źródeł zewnętrznych (lata 2012-2014 - brak możliwości finasowania innowacji ze źródeł zewnętrznych). Duże znaczenie tego problemu wskazało od 18,7\% (lata 2012-2014) do 29,7\% (lata 2004-2006) ogółu przedsiębiorstw przemysłowych. Czynniki te niezmiennie zajmują 1 i 2 lokatę pod względem największego odsetka wskazań na określoną przeszkodę o dużym znaczeniu w trzech kolejnych edycjach badań. Obok barier kosztowych istotne ograniczenia w działalności innowacyjnej wywołują czynniki rynkowe. Niepewny popyt na innowacyjne produkty (lata 2012-2014 - niepewny popyt na rynku na pomysły na innowacje) uznało za przeszkodę dla opracowywania i wdrażania nowych lub istotnie ulepszonych rozwiązań od 17,3\% (lata 2012-2014) do 21,5\% (lata 2008-2010)

tyfikację przeszkód dla innowacji w sprawozdaniach, które będą obowiązywać w 2018 r. Wówczas gromadzone dane dotyczyłyby lat 2015-2017, a nie jak w formularzach z 2017 r. - okresu 2014-2016. Przyjęty okres obserwacji w 2017 r. częściowo pokrywa się z perspektywą z 2015 r., która odnosiła się do lat 2012-2014. Uchybienie to podważa zasadność porównania wyników aktualnie prowadzonych badań z ich poprzednią edycją. 
Tabela 2. Czynniki utrudniające działalność innowacyjną przedsiębiorstw woj. dolnośląskiego

\begin{tabular}{|c|c|c|c|c|c|c|c|c|c|c|c|c|}
\hline \multirow{3}{*}{ Przeszkody } & \multicolumn{6}{|c|}{ Przemysł } & \multicolumn{6}{|c|}{ Usługi } \\
\hline & \multicolumn{2}{|c|}{$\begin{array}{l}2004- \\
-2006\end{array}$} & \multicolumn{2}{|c|}{$\begin{array}{l}2008- \\
-2010\end{array}$} & \multicolumn{2}{|c|}{$\begin{array}{l}2012- \\
-2014\end{array}$} & \multicolumn{2}{|c|}{$\begin{array}{l}2004- \\
-2006\end{array}$} & \multicolumn{2}{|c|}{$\begin{array}{l}2008- \\
-2010\end{array}$} & \multicolumn{2}{|c|}{$\begin{array}{l}2012- \\
-2014\end{array}$} \\
\hline & $\mathrm{O}$ & $\mathrm{L}$ & $\mathrm{O}$ & $\mathrm{L}$ & $\mathrm{O}$ & $\mathrm{L}$ & $\mathrm{O}$ & $\mathrm{L}$ & $\mathrm{O}$ & $\mathrm{L}$ & $\mathrm{O}$ & $\mathrm{L}$ \\
\hline $\begin{array}{l}\text { Brak środków finansowych } \\
\text { w przedsiębiorstwie lub } \\
\text { grupie przedsiębiorstw }\end{array}$ & 36,7 & 1 & 32,8 & 1 & 29,3 & 1 & 20,0 & 1 & 25,8 & 1 & 12,2 & $2-3$ \\
\hline $\begin{array}{l}\text { Brak środków finansowych } \\
\text { ze źródeł zewnętrznych }\end{array}$ & 29,7 & 2 & 26,7 & 2 & 18,7 & 2 & 19,2 & 2 & 22,1 & 2 & 10,9 & 5 \\
\hline $\begin{array}{l}\text { Brak wykwalifikowanego } \\
\text { personelu }\end{array}$ & 10,1 & 6 & 15,7 & 6 & 12,9 & 5 & 11,7 & 5 & 13,9 & 6 & 6,1 & 8 \\
\hline $\begin{array}{l}\text { Trudności w znalezieniu } \\
\text { partnerów do współpracy }\end{array}$ & 9,5 & 7 & 17,9 & 5 & 9,2 & 7 & 9,0 & 6 & 13,7 & 8 & 8,0 & 6 \\
\hline $\begin{array}{l}\text { Niepewny popyt na } \\
\text { innowacyjne produkty }\end{array}$ & 19,0 & 4 & 21,5 & 4 & 17,3 & 3 & 18,2 & 3 & 18,2 & 4 & 13,3 & 1 \\
\hline $\begin{array}{l}\text { Rynek opanowany } \\
\text { przez dominujące } \\
\text { przedsiębiorstwa }\end{array}$ & 19,7 & 3 & 22,0 & 3 & 15,9 & 4 & 12,9 & 4 & 20,1 & 3 & 12,2 & $2-3$ \\
\hline $\begin{array}{l}\text { Brak potrzeby wdrażania } \\
\text { innowacji ze względu na } \\
\text { wcześniejsze innowacje }\end{array}$ & 8,7 & 8 & 13,4 & 8 & 3,3 & 8 & 8,6 & 7 & 13,8 & 7 & 11,3 & 4 \\
\hline Brak popytu na innowacje & 11,2 & 5 & 15,0 & 7 & 9,4 & 6 & 8,4 & 8 & 15,4 & 5 & 7,3 & 7 \\
\hline
\end{tabular}

$\mathrm{O}$ - odsetek wskazań przedsiębiorstw na duże znaczenie określonej przeszkody dla innowacji;

L - lokata pozycjonująca przeszkody utrudniające działalność innowacyjną od najwyższego do najniższego odsetka wskazań na ich duże znaczenie.

Źródło: opracowanie własne na podstawie [GUS 2008, s. 163; GUS - Urząd Statystyczny w Szczecinie 2011, s. 248; GUS - Urząd Statystyczny w Szczecinie 2015, tab. 5(97)-6(98)].

respondentów. Ich równie znaczny odsetek sądzi, że rynek jest opanowany przez dominujące przedsiębiorstwa (lata 2004-2006 i 2008-2010) lub panuje na nim zbyt duża konkurencja (lata 2012-2014). W pogląd ten wpisało się od 15,9\% (lata 2012-2014) do 22,0\% (lata 2008-2010) dolnośląskich przedsiębiorstw przemysłowych. Wymienione czynniki rynkowe zamiennie zajmują 3 i 4 lokatę wśród najczęściej wskazywanych problemów. Pozostałe bariery działalności innowacyjnej - uogólniając wyniki ze wszystkich okresów objętych obserwacją - nie odgrywały już tak istotnej roli.

W sektorze usługowym, podobnie jak w grupie przedsiębiorstw przemysłowych, najistotniejsze przeszkody dla innowacji wywołują czynniki kosztowe i rynkowe, choć ich pozycjonowanie nieco się różni w trzeciej edycji badań w relacji do wcześniejszych obserwacji.

W latach 2004-2006 i 2008-2010 na brak środków finansowych w przedsiębiorstwie lub grupie przedsiębiorstw wskazywało od 20,0\% (lata 2004-2006) do 25,8\% 
(lata 2008-2010) badanych jednostek, a na brak środków ze źródeł zewnętrznych od 19,2\% (lata 2004-2006) do 22,1\% (lata 2008-2010). Czynniki te zajęły 1 i 2 lokatę pod względem największego odetka wskazań na określoną przeszkodę o dużym znaczeniu. Kolejne dwa miejsca przypadły w udziale barierom rynkowym. Niepewny popyt na innowacyjne produkty oraz opanowanie rynku przez dominujące przedsiębiorstwa postrzegało w kategoriach istotnych utrudnień działalności innowacyjnej odpowiednio 18,2\% (lata 2004-2006 i 2008-2010) oraz od 12,9\% (lata 2004-2006) do 20,1\% (lata 2008-2010) podmiotów usługowych. Pozostałe przeszkody nie były już tak uciążliwe. Sytuacja ta zmieniła się w trzeciej edycji badań. W latach 2012-2014 niepewny popyt na innowacyjne produkty był najczęściej wskazywany przez usługodawców jako istotne ograniczenie ich procesów innowacyjnych. Drugą i trzecią lokatę w tym rankingu zajęły ex aequo brak możliwości finansowania innowacji ze źródeł wewnętrznych przedsiębiorstwa oraz zbyt duża konkurencja na rynku $(12,2 \%$ wskazań). Na kolejnych miejscach uplasowały się ograniczenia w postaci braku potrzeby wdrażania innowacji ze względu na wcześniejsze innowacje oraz braku możliwości finansowania innowacji ze źródeł zewnętrznych (odpowiednio 11,3\% i 10,9\% wskazań). Pozostałe bariery istotnie odczuwało mniej niż $10 \%$ respondentów.

\section{Zakończenie}

Z przeprowadzonych rozważań wynika, że:

- sprawozdania o innowacjach w przemyśle i sektorze usług operują uboższym zestawem potencjalnych przeszkód dla innowacji niż Oslo Manual 2005,

- zmiana obserwowanych utrudnień i ich nazewnictwa w ramach PNT-02 i PNT-02/u wywołuje wątpliwości interpretacyjne oraz wprowadza ograniczenia w zakresie analizy porównawczej w czasie,

- marginalizuje się problematykę przeszkód dla innowacji przez wybory minimalistycznych rozwiązań OM 2005 (najmniejsza powtarzalność badań, najdłuższy, możliwy okres obserwacji),

- przedsiębiorstwa przemysłowe i usługowe województwa dolnośląskiego za najistotniejsze przeszkody dla innowacji uznają czynniki kosztowe i rynkowe.

\section{Literatura}

GUS - Urząd Statystyczny w Szczecinie, 2011, Działalność innowacyjna przedsiębiorstw w latach 2008-2010, Warszawa.

GUS - Urząd Statystyczny w Szczecinie, 2015, Działalność innowacyjna przedsiębiorstw w latach 2012-2014 - tablice, Warszawa.

GUS, 2007a, PNT-02. Sprawozdania o innowacjach w przemyśle za lata 2004-2006, Warszawa.

GUS, 2007b, PNT-02/u. Sprawozdanie o innowacjach w sektorze ustug za lata 2004-2006, Warszawa. GUS, 2008, Działalność innowacyjna przedsiębiorstw w latach 2004-2006, Warszawa.

GUS, 2011a, PNT-02. Sprawozdania o innowacjach w przemyśle za lata 2008-2010, Warszawa. 
GUS, 2011b, PNT-02/u. Sprawozdanie o innowacjach w sektorze ustug za lata 2008-2010, Warszawa. GUS, 2015a, PNT-02. Sprawozdania o innowacjach w przemyśle za lata 2012-2014, Warszawa.

GUS, 2015b, PNT-02/u. Sprawozdanie o innowacjach w sektorze ustug za lata 2012-2014, Warszawa. GUS, 2017a, PNT-02. Sprawozdania o innowacjach w przemyśle za lata 2014-2016, Warszawa.

GUS, 2017b, PNT-02/u. Sprawozdanie o innowacjach w sektorze ustug za lata 2014-2016, Warszawa. OECD/European Communities, 2005, Oslo Manual: Guidelines for Collecting and Interpreting Innovation Data, 3rd Edition. 